\title{
Improvised Music in Berlin 2012-13: A Brief Ethnographic Portrait
}

\section{Tom Arthurs}

This paper is an adaptation of the first chapter of the ethnographic section of my forthcoming PhD thesis "The Secret Gardeners: An Ethnography of Improvised Music in Berlin (2012-13)," which is a wider-reaching text that uses an interdisciplinary approach founded in Grounded Theory, Ethnography and Social Network Analysis to address the aesthetics, ideologies and practicalities of contemporary European Improvised Music-making from the point of view of 34 key practitioners and "expert" listeners. ${ }^{1}$

While the primary focus of my thesis is music-making itself (and an attempt to suggest a range of conventions and distinctions underlying Improvised Music consumption and production), this article serves as an introduction and background to Berlin's cosmopolitan scene of 2012 and 2013, presenting a portrait of a small, "hidden," closely-knit, international, and ever-changing scene that encompassed those of all ages, existed almost entirely outside of the mainstream, and sustained itself on low budgets and a considerable amount of goodwill.

While this paper will provide little of surprise for those already familiar with Improvised Music scenes the world over, I nonetheless hope that for those new to the field, this article will provide a fitting introduction to the social context within which today's Improvised Music practices take place, also highlighting issues of diversity and economics rarely addressed elsewhere.

Using quantitative findings (from SPSS Statistics and Social Network Analysis) and interviews and observations from 66 concerts visited during fieldwork, I will show the size, structure and constitution of the scene, focusing firstly on performers and secondly on venues (this section will also suggest some stylistic and social boundaries for the scene itself). A third section will discuss the audience for Improvised Music (its size and constitution), and a fourth will provide an introduction to the economics of the scene and identify the problems this posed for Berlin's improvisers, as well as listing many of the practical solutions that musicians developed in order to deal with this reality.

These findings identify a general social location for contemporary Improvised Music-making, as well identifying key themes for consideration in the future development and legitimization of such music and musicians.

Berlin was chosen as the site for fieldwork given its current position as one of the worlds' most important cities for Improvised Music-making, in terms of both its size and the range of differing-yet-interrelated practices represented there (including, but not limited to, Free Jazz, Post-Free Jazz, (Post-)Reductionism, Electroacoustic Improvisation, Textural Improvisation, Noise and Durational playing). ${ }^{2}$

\section{Performers: Facts and Figures}

\section{Age, Gender and Origin}

According to the archives of the website http://www.echtzeitmusik.de, ${ }^{3} 1274$ performers participated in 969 events including Improvised Music during the calendar year 2012. ${ }^{4}$

Of these performers, 1078 were musicians, alongside 13 DJs, 63 dancers, 46 visual artists, 11 performance artists, 3 Poets and 1 chef. $^{5}$ The nature of participation was unclear (or unknown) for 59 performers, and Table 1 shows the distribution of primary instruments and activities. ${ }^{6}$ 


\begin{tabular}{|c|c|c|c|c|c|}
\hline Accordion & 4 & Guitar & 96 & 'Sound' & 1 \\
\hline Bass & 105 & Harmonica & 1 & Toy Piano & 1 \\
\hline Bass Clarinet & 10 & Harp & 2 & Trombone & 23 \\
\hline Bassoon & 1 & Melodica & 1 & Trumpet & 29 \\
\hline Cello & 31 & 'Objects'/'Toys' & 5 & Tuba & 4 \\
\hline Chef & 1 & Organ & 6 & Turntables & 2 \\
\hline Clarinet & 18 & Percussion & 29 & Unknown & 59 \\
\hline Dance & 63 & Perf. Artist & 11 & Vibraphone & 7 \\
\hline DJ & 13 & Piano & 83 & Viola & 10 \\
\hline Drums & 115 & Poet & 3 & Violin & 32 \\
\hline Electronics & 259 & Recorder & 3 & Visuals & 46 \\
\hline Flute & 13 & Saxophone & 129 & Voice & 55 \\
\hline French Horn & 1 & Sitar & 1 & Zither & 1 \\
\hline & & & & \\
\hline
\end{tabular}

Table 1. Main instrument/activity

Ages ranged from 18 to 82 (with a mean age of 41 ), and the distribution of all ages is shown in Figure 1. Perhaps unlike in other musical genres, it was common for musicians of all ages to collaborate; 29-year-old Australian bassist Mike Majkowski regularly performed with musicians aged between 22 and 74, having the widest range in this respect.

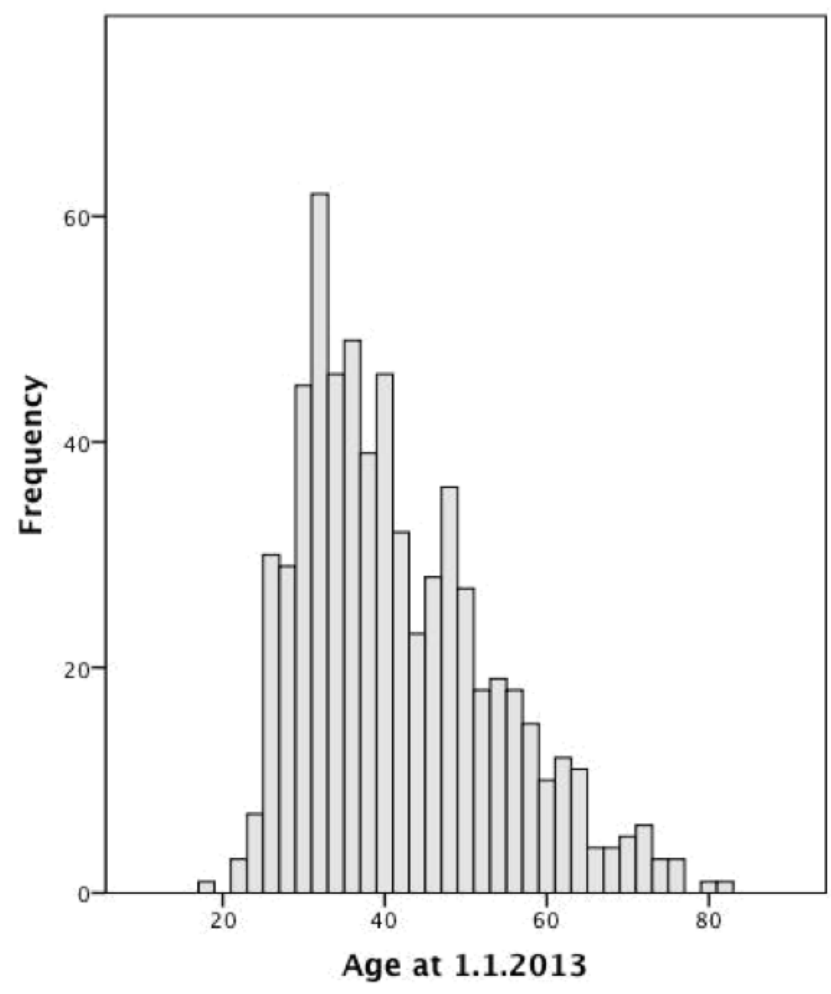

Figure 1. Participants' age 
The scene was $77 \%$ male, rising to $80-85 \%$ for those with interests in jazz, noise/drone/industrial and pop/rock/world musics. A higher proportion of those interested in dance and visual art ( $37 \%$ and $32 \%)$ were female, and, on average, women were more likely to have a greater number of women in their social networks $(33 \%)$ than men $(18 \%)$.

One club's social network was as high as $93 \%$ male, ${ }^{7}$ however, many female participants described how, even with such a skewed demographic, it was still easier to be accepted as a woman in the Improvised Music world than in the jazz scene. Many women I interviewed were critical of men who performed only with men (especially in more jazz-related areas), but this was often met with the retort that this was not out of sexism or discrimination, but that, as one drummer put it, "if there was a woman who could play like [named a male colleague] then I would play with her."

On the other hand, there were also examples of positive discrimination (especially from the Echtzeitmusik-scene and non-jazz-related areas), with the promoters of Labor Sonor aiming to curate male and female performers equally ${ }^{8}$ and the Quota; Unquota concert series at the Lichtblick Kino, which promoted only female musicians. Despite the fact that the first generation of American and European improvisers was almost exclusively male, ${ }^{9}$ it was felt by contemporary musicians that the field was now open to all (although occasional sexist judgments and discrimination still occurred). ${ }^{10}$

$27 \%$ of all participants were German, $73 \%$ were international; however, just less than half of all participants were resident in Berlin — a testament to the importance of the city as a worldwide social hub for Improvised Music. ${ }^{11}$ So far as was clear from the available biographical information, only 13 musicians were born in Berlin.

Figure 2 shows the year that those resident in Berlin moved to the city, confirming a marked increase in migration (and the size of the Improvised Music community as a whole) since $1990 .^{12}$ Figure 3 shows the age at which participants moved to Berlin (mainly in their 20s and early 30s), and Figure 4 makes clear that international migration took place mainly after the year 2000 . Of residents, $43 \%$ were German and $25 \%$ were women (slightly higher than the average for the entire scene).

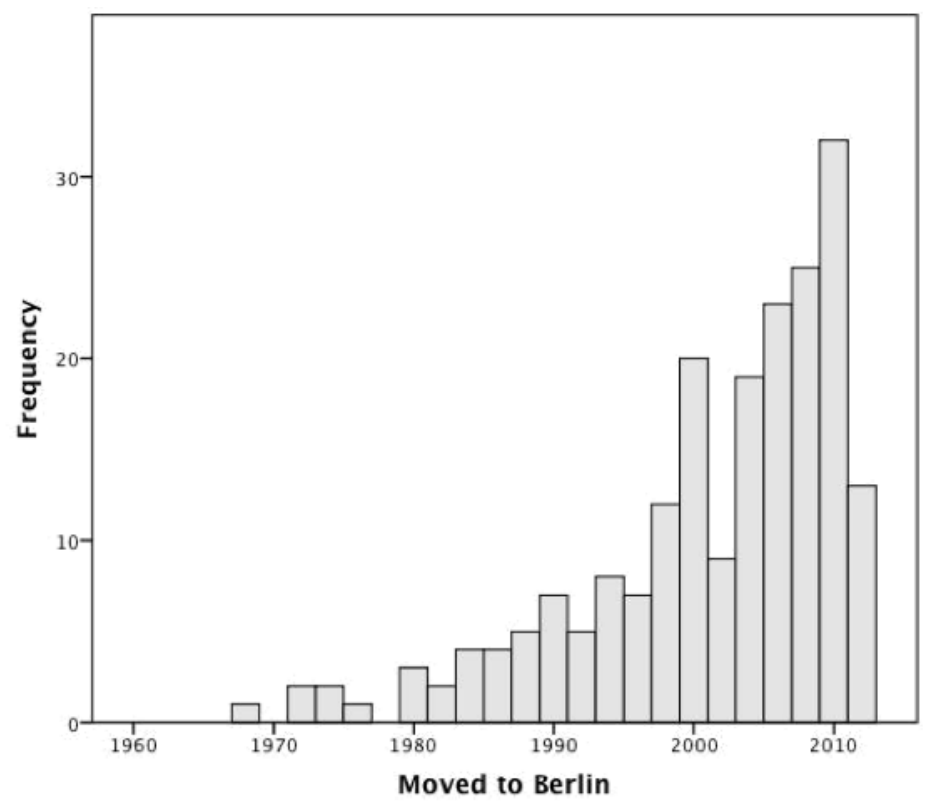

Figure 2. Date moved to Berlin 


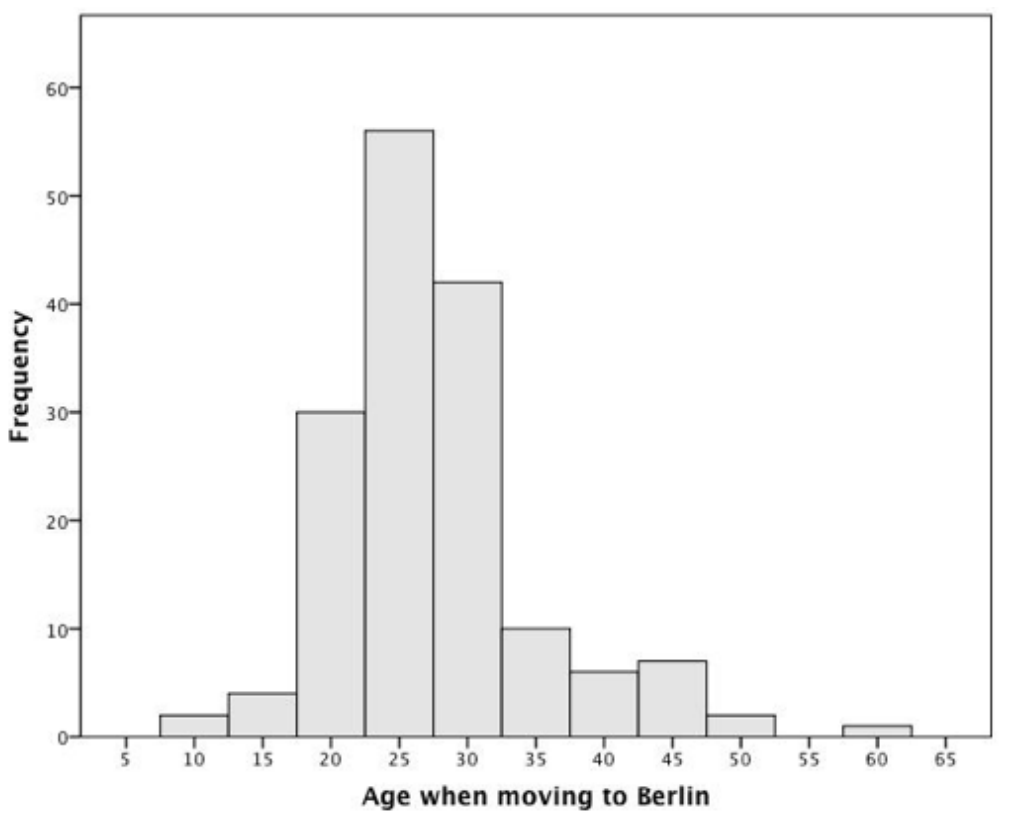

Figure 3. Age moved to Berlin

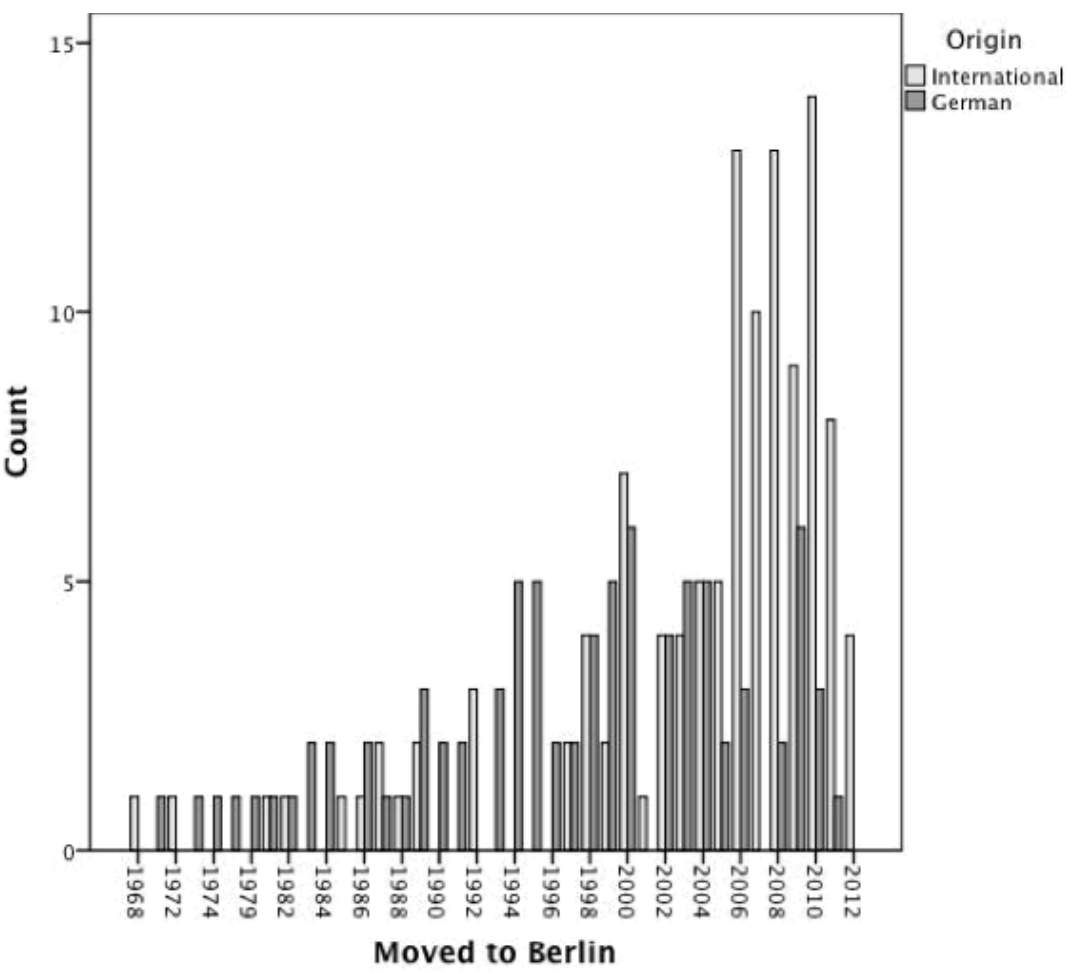

Figure 4. International migration to Berlin

Table 2 shows the ten most popular origins of Berlin-resident musicians, and this distribution accounted for over three-quarters of Berlin-based participants. This confirmed a picture of an almost-entirely white and "first-world" community, ${ }^{13}$ and, along with findings from interviews, this suggested a scene with relatively middle/professional class_-and perhaps surprisingly conventional-roots. 


\begin{tabular}{|c:c|}
\hline Germany & 249 \\
\hline Italy & 38 \\
\hline USA & 37 \\
\hline Japan & 27 \\
\hline UK & 18 \\
\hline Australia & 17 \\
\hline Austria & 14 \\
\hline Switzerland & 13 \\
\hline France & 12 \\
\hline Sweden & 10 \\
\hline
\end{tabular}

Table 2. Ten most common origins of Berlin improvisers

Paternal occupations included engineers, teachers (of music and not), workers in housing and urban development, professors (of subjects including chemistry and animal behaviour), an economist, an export salesman for steel, a prominent Hamburg ship-broker, and a travelling shoe salesman.

Maternal professions included many housewives (especially among older musicians), a scientist, an architect who lectured in museology/museography, a patent searcher, teachers, architects, translators and booksellers. Exceptions to these more conventional backgrounds included an opera-singing mother, the sons of a "professional" Italian communist and his scientist wife, rock and roll musicians (both parents), and the daughter of farmers.

\section{Structure}

When analyzed using the tools of Social Network Analysis (SNA), the scene showed a clear core and periphery structure, as demonstrated by the 1-mode performer-performer network shown in Figure 5 \& Figure 6.

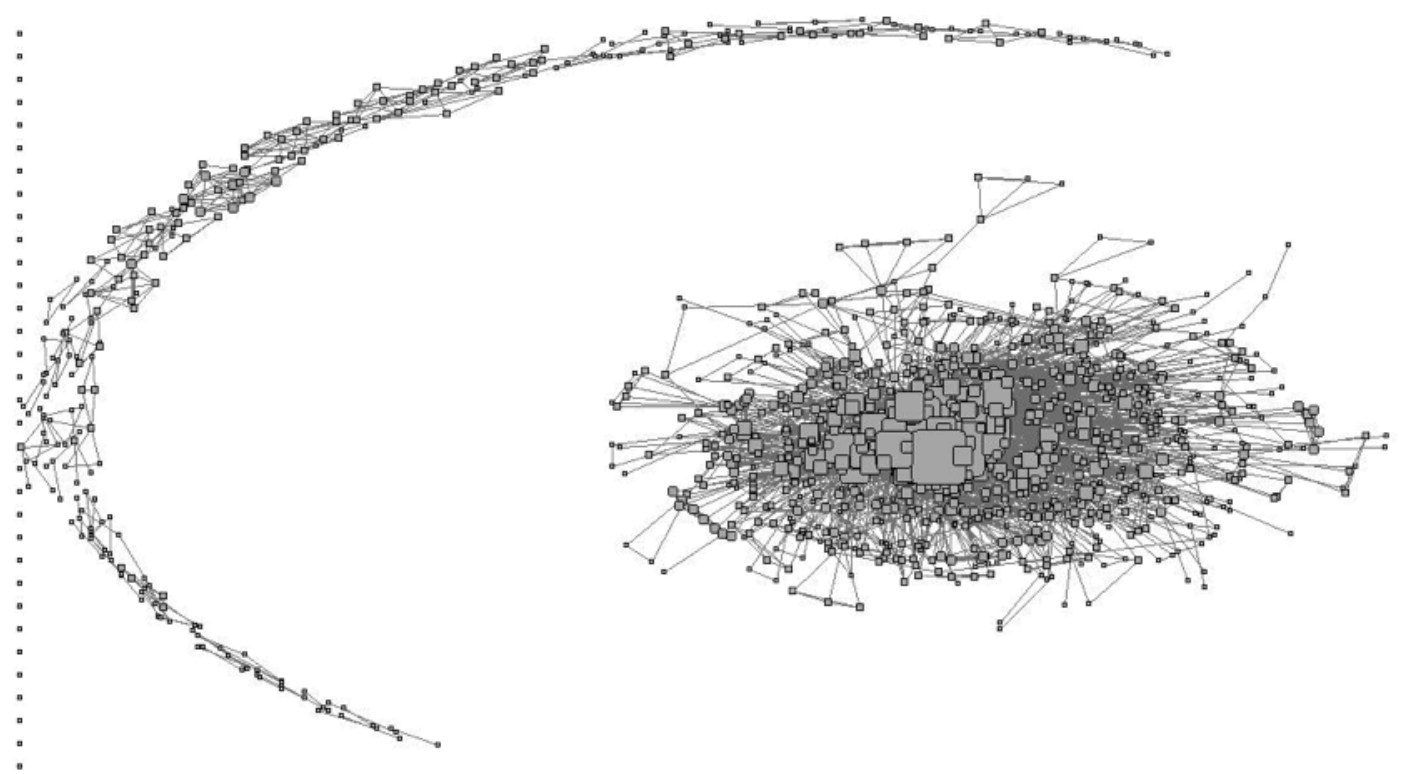

Figure 5. Entire social network of Improvised Music in Berlin, node size set by degree centrality. Image produced using UCINET (Borgatti et al., 2002) 


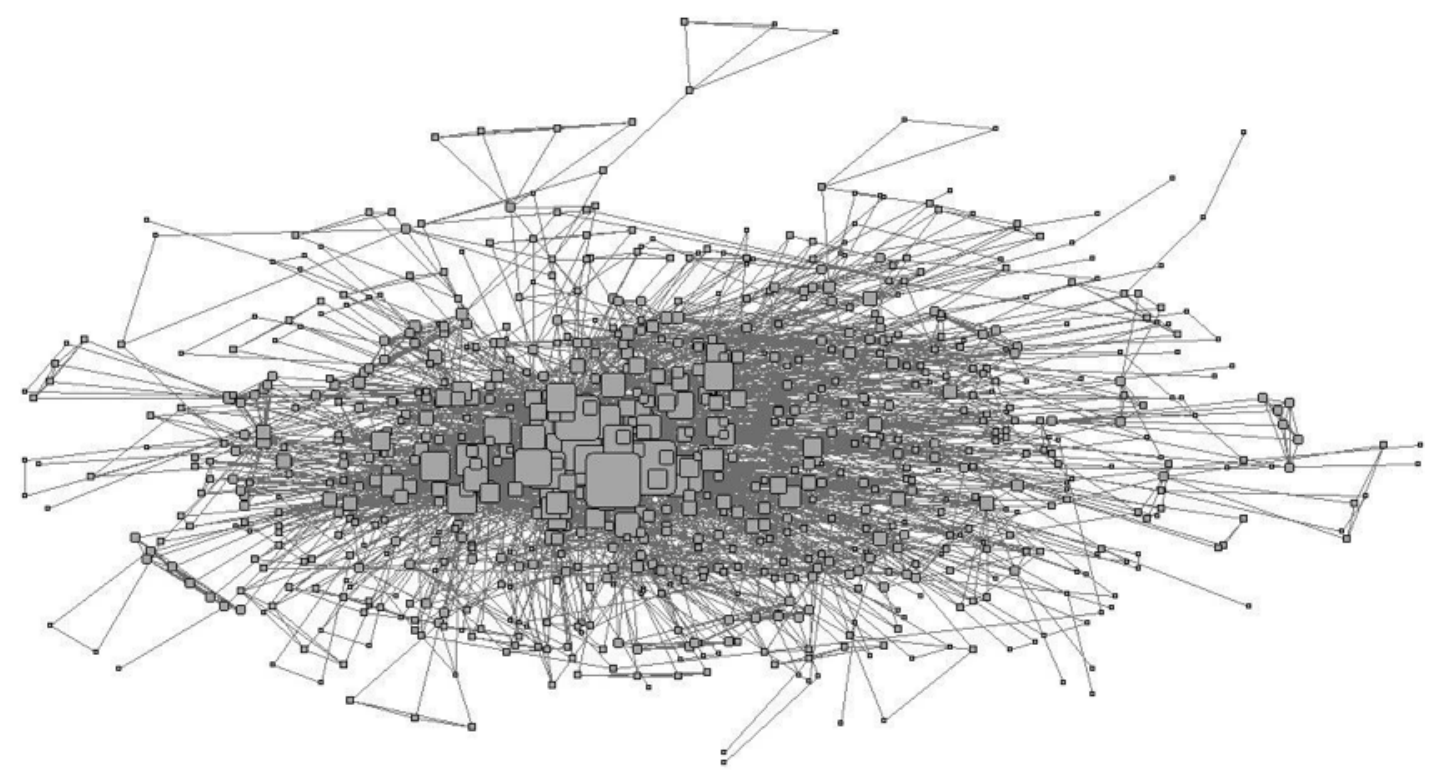

Figure 6. Entire social network of Improvised Music in Berlin, main component only, node size set by degree centrality. Image produced using UCINET (Borgatti et al., 2002)

When connected in a 2-mode network (venues and performers), only 2 venues and 5 performers remained unconnected. This (and the 1-mode network above) suggests a closely-knit core scene. This view is compounded by the inversely proportional relationship between network density and group size shown in Figure 7. This diagram suggests a core community of between 100 and 200 performers, ${ }^{14}$ and the network (as a whole) shows that musicians would play together in many different combinations (rather than having loyalties to just one or two projects as, perhaps, in the case of rock and pop music). Musicians also often played in constellations that performed several times over the course of a year (in addition to one-off, "ad-hoc", events).

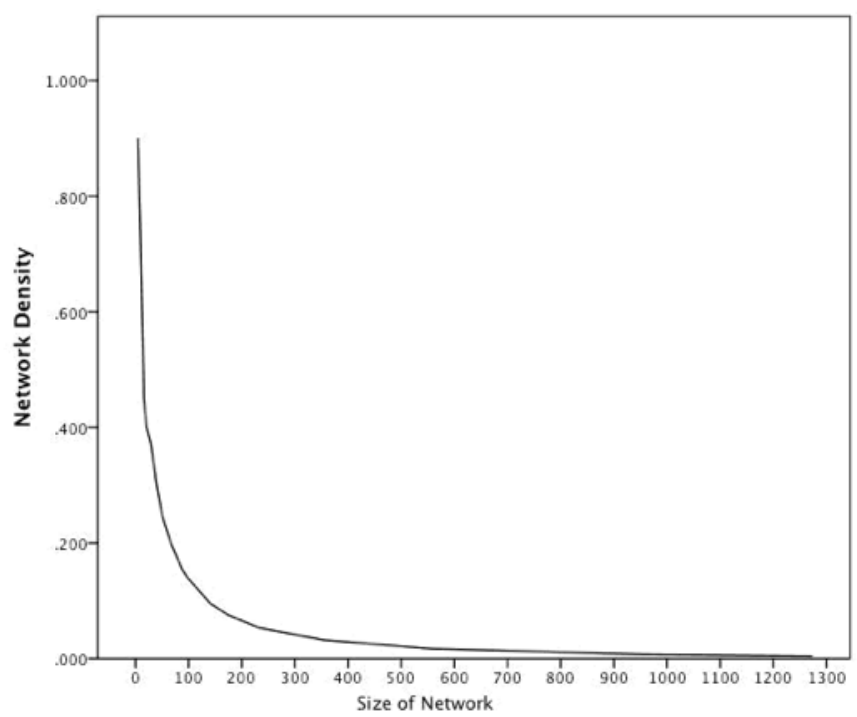

Figure 7. Size of social network based on degree centrality scores, related to network density

My initial hope was that SNA would clearly identify various sub-scenes and communities (using techniques such as cliques and $\mathrm{K}$-cores), however, the scene turned out to be much more complex, with many musicians moving between various sub-styles of Improvised Music (and venues) in very different and often quite personal ways. ${ }^{15}$

The only relationships clearly visible from SNA were a concentrated scene of those with interests in jazz and Free Jazz (as opposed to those using electronics) and a clique of German musicians with interests in jazz and Free Jazz (see Figure 8, Figure 9, and Figure 10). As might be expected, musicians who organized events and/or record labels were generally more central to the social network, whereas those with interests in Neue Musik, ${ }^{16}$ theatre, visual art, and dance (as well as distributions of age and origin) remained more scattered, seemingly without connection. 


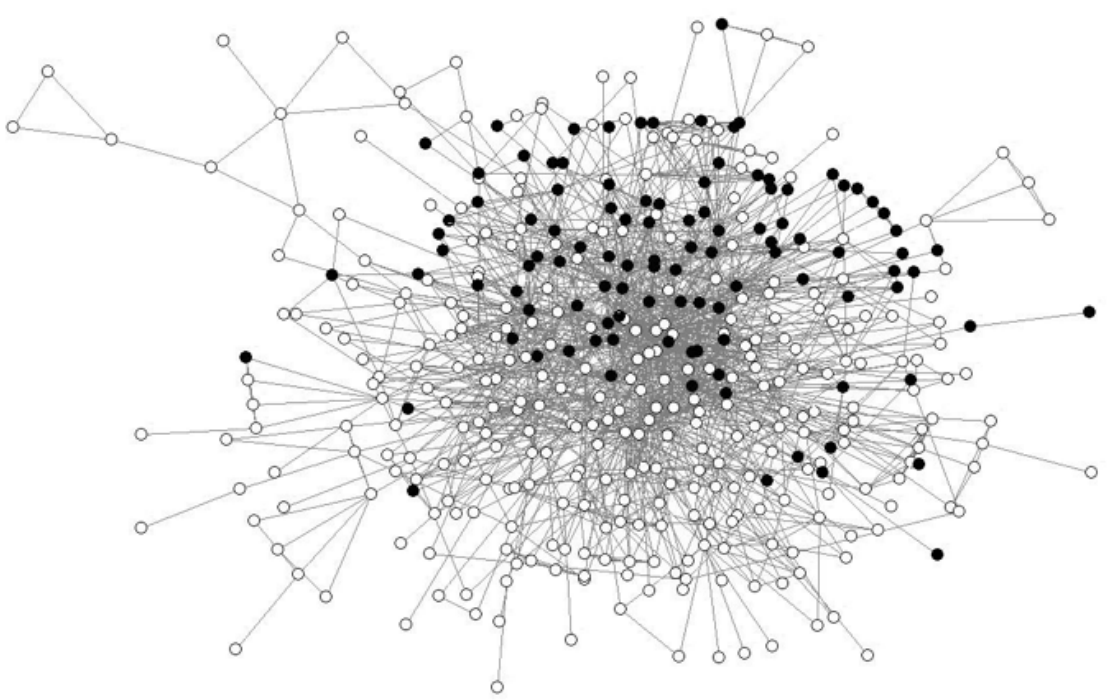

Figure 8. Those with interests in jazz, Berlin residents only

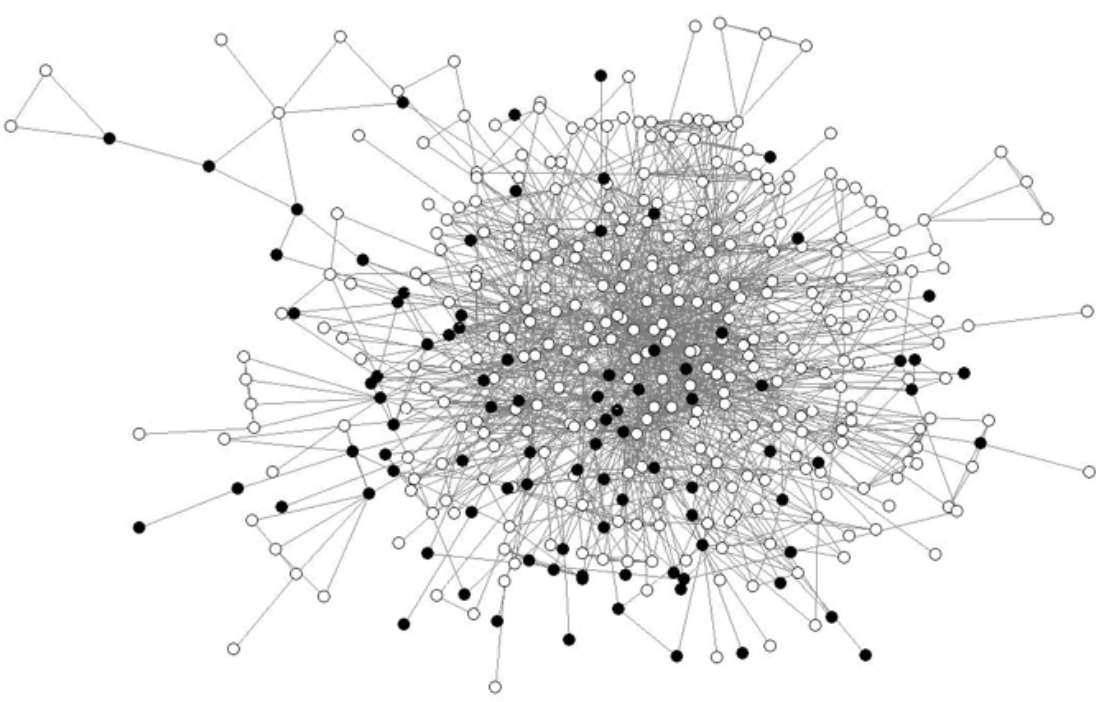

Figure 9. Those using electronics, Berlin residents only

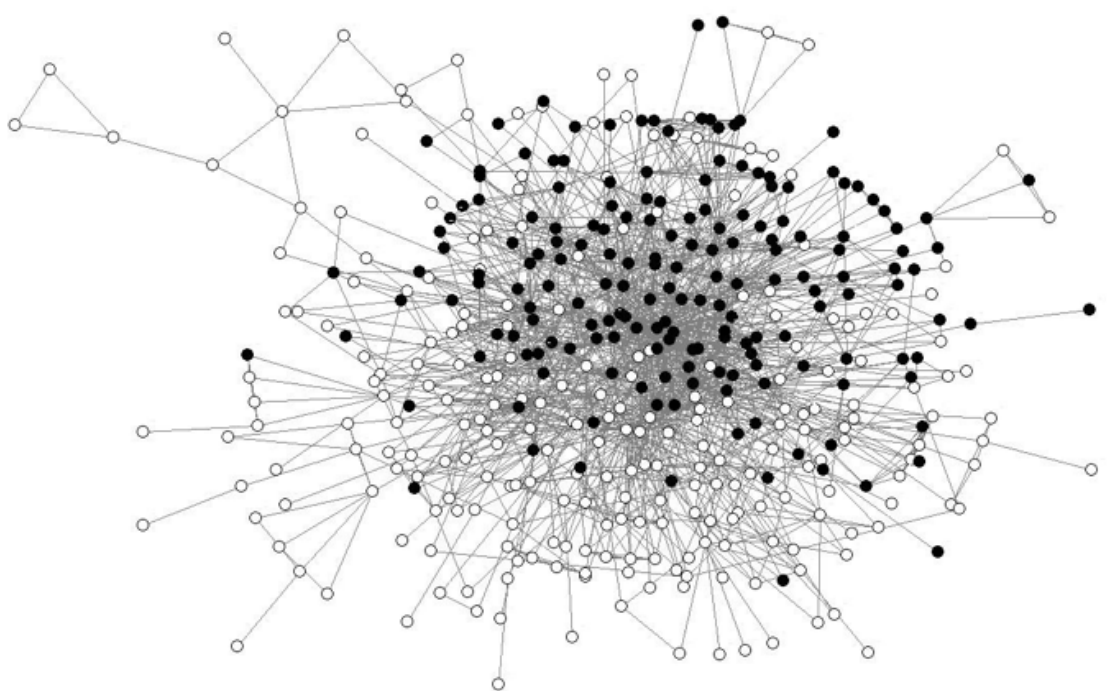

Figure 10. German participants with interests in jazz, Berlin residents only 
Closer inspection of these diagrams ${ }^{17}$ showed that while some musicians' social networks were limited to one small area of this overall picture, many spanned several different regions, and accordingly, the romantic idea of the musician (or artist) with one line of output, conveniently grouped into social cliques of those with similar interests, clearly did not apply in the case of Berlin's Improvised Music scene.

\section{Venues}

In 2012, Improvised Music performances in Berlin took place in 155 venues, including independent art galleries, former squatted houses, and semi-legal bars (transformed from butchers' shops and brothels); private houses, salons and rehearsal spaces; as well as mainstream jazz clubs, churches, interdisciplinary performance spaces, ${ }^{18}$ the Institut Français, and even Berlin's central station.

The geographical distribution of these venues is shown in Figure 11, and this map shows clusters in the districts of Prenzlauer Berg and Mitte (the now-gentrified sites of 1990s post-GDR squatting), as well as in Kreuzberg 10999 and Neukölln (a significant site of gentrification since about 2008). ${ }^{19}$

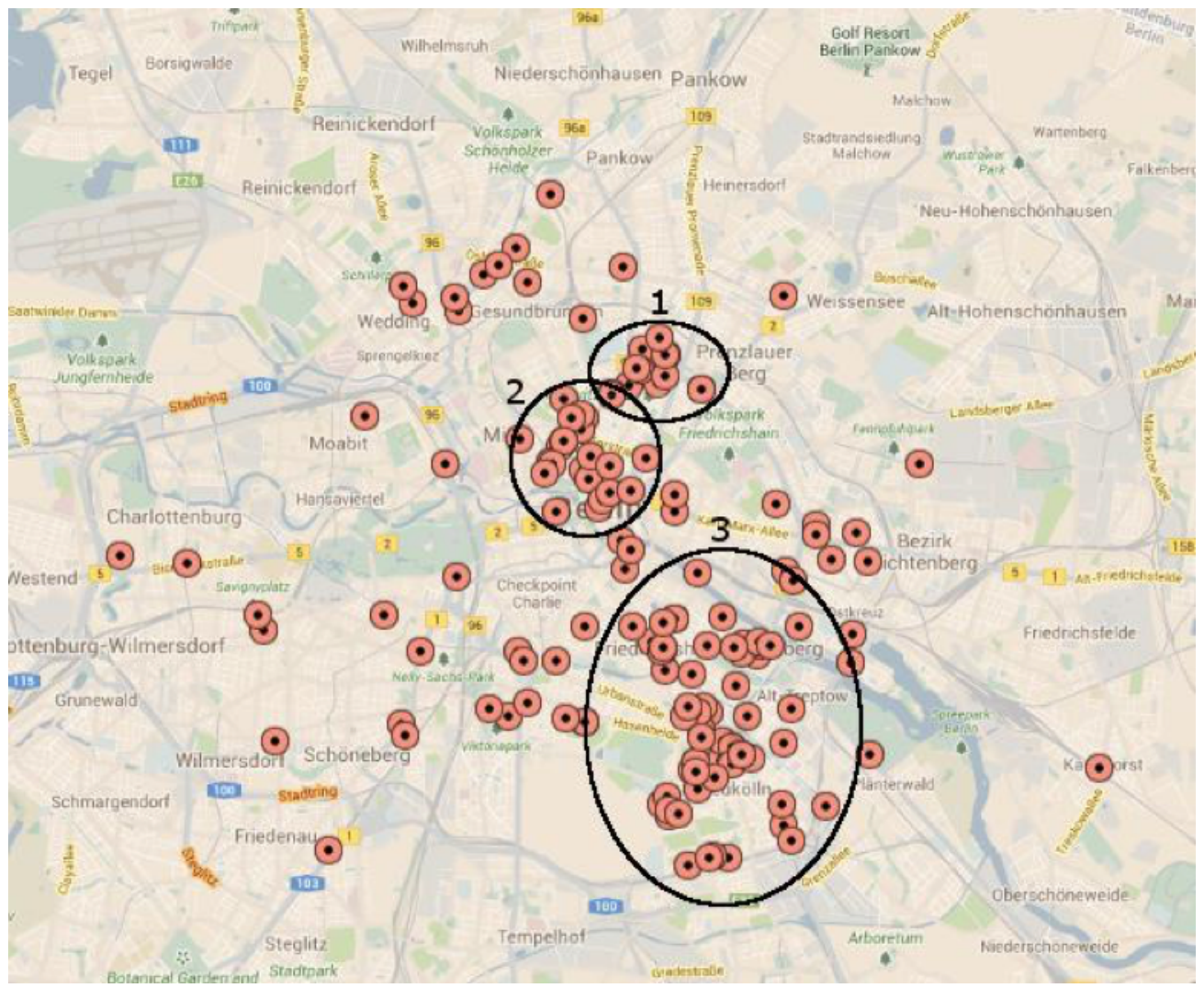

Figure 11. Map of Berlin Improvised Music venues in (1) Prenzlauer Berg, (2) Mitte and (3) Kreuzberg/Neukölln. Two venues in Potsdam and Zepernick, outside the bounds of this map, have been omitted. Map data @ Google 2014

The ten most socially important venues emerging from SNA (defined by degree centrality and listed in descending order) were Sowieso, Ausland, Naherholung Sternchen, Jazzkeller 69 in Aufsturz, Madame Claude, Quiet Cue, Lichtblick Kino, a private salon formerly located in Mitte but that moved to the up-and-coming district of Wedding in $2013,{ }^{20}$ The Great Heisenberg and Wendel, and these venues fell mostly into two camps: "adhoc"/DIY-style bars and neutral, studio-like performance spaces and theatres. ${ }^{21}$

Bars and performance spaces were relatively informal settings - many were, perhaps, not entirely legal ${ }^{22}$-and audiences and performers often mingled with one another, many venues being too small to have dressing rooms or stages (audience and performers were on the same level).

Many were extremely hard to find, without signs or literally hidden underground (Ausland, Madame Claude and Sucked Orange Gallery); Marie Antoinette was obscured behind an office block (in railway arches near to Jannowitzbrücke station); ${ }^{23}$ and NK was in the second floor of a darkened courtyard, directly above a 24-hour commercial bakery. 
"Ad-hoc" bars were typically decorated with a selection of second-hand or self-built furniture, as well as various other second-hand, gifted or "found" items and artworks. By means of example, the Sowieso menu was written in marker pen on an antique mirror hung behind the bar, faded tiles from the venue's former days as a butchers' shop adorned the floor and walls (in some parts overlaid with decadent gilded wallpapers), and an upturned candelabra with multicolored bulbs hung, elegantly, from a wood-paneled ceiling.

The old salon in Mitte was similarly distinct-visitors rang an unassuming doorbell to gain access to the building and, once inside, the walls of the house's main entrance were already covered by a collage of street- and cutoutart, as was the stairway that led up from a typical Berlin residential courtyard to a $35 \mathrm{~m}^{2}$ residential flat. ${ }^{24}$ Entering the concert room was like entering a parallel universe-every conceivable inch of wall and ceiling space was adorned with texts, collages and paintings (by various artist friends of the hosts). Such artworks included a Japanese depiction of the Mexican day of the dead, a giant papier mâché washing machine with a protruding light shaped like an alien eye, a golden octopus (hung from the ceiling in its own net), and a small wooden box marked "Theatre du Jour" (containing three friendly, yet slightly sinister, stuffed figures). There was poetry on the ceiling and, as you entered the main room, a small text at knee level declared "Arbeit macht frei. Nicht arbeiten macht freier." ${ }^{25}$ Behind the handmade bar, two men of around 40, a suited Tyrolean who spoke something of every language under the sun (also a woodworker and sometime professional waiter) and a Japanese shop and restaurant outfitter (with pony tail and whiskers), served fine wines, soup and famously large doses of single malt whiskies.

Elsewhere, black- or white-box performance spaces such as the concert room in KuLe (where the series Labor Sonor was held), Quiet Cue, Galerie Zeitzone, and Ausland (actually a concrete bunker with a self-built bar overlooked by a fur-covered soundbooth accessible by metal ladder) were also used-especially for performances related to the Echtzeitmusik scene. ${ }^{26}$ Bassist Alexander Frangenheim's studio Boerne45, the upstairs rooms at Radialsystem $\mathrm{V}$ and Tanzfabrik were all fitted out like dance studios, and the Exploratorium was similarly reminiscent of this kind of environment - with wooden floors, mirrors and white walls.

This list of venues points to the continued fleetingness of the scene itself, and while KuLe had been used for Labor Sonor since 2000 and Ausland existed since 2002, most of the other Improvised Music venues of the late1990 s had ceased to be. In Neukölln, Sowieso and Quiet Cue opened in 2008 and $2009,{ }^{27}$ but many other venues recorded by Blazanovic in 2010, including Strahlau 68, Die Remise, the Electronic Church and Raum20 (all of which opened after 2000), had fallen by the wayside by the time my fieldwork began. ${ }^{28}$

Changing, but remaining in 2013, Naherholung Sternchen dramatically reduced its Improvised Music programming (presenting only festivals as opposed to single concerts) and, as mentioned above, the salon disappeared from its home in fashionable Mitte, only to reappear some months later in a former industrial building in the upcoming district of Wedding. Allegedly owing to a dispute between the owners, The Great Heisenberg (beloved by many musicians) shut suddenly in the Spring, and Neukölln's Sucked Orange Gallery was under constant threat from neighbours, the police and the owners of the house. ${ }^{29}$

On the other hand, every couple of months, new venues would spring into life, and the Ackerstadt Palast (a black-box theatre for 60-70 people in the courtyard behind two other clubs in Mitte) began programming Improvised Music alongside dance and performance art, ${ }^{30}$ while the Direktorenhaus (promoted by Assi Glöde of Jazzkeller69, alongside the Umlaut collective and Jazzkollektiv Berlin) opened for a few months, before disappearing because of low attendance.

\section{Other Uses}

As with performers themselves, ${ }^{31}$ venues showed varying degrees of commitment to Improvised Music, and their other activities also served to suggest the aesthetic and social boundaries of the scene itself-providing a sense of the wider context to which today's scene belonged.

Sowieso was the only venue entirely devoted to Improvised Music (programming every night from Tuesday to Saturday), whereas other venues varied dramatically-from those promoting one concert a year, to those with one concert per week, one per month, or those with only occasional nights and one-off festivals.

The B Flat also promoted mainstream jazz, and Aufsturz (home to Jazzkeller69) mainly programmed rock bands for the remaining six nights of the week (all of the B Flat was programmed by the same in-house promoter, whereas other programming in Aufsturz was unrelated to Assi Glöde's control of the Jazzkeller). Similarly, former brothel Madame Claude hosted the electronic Improvised Music night Experimontag on Mondays, but the rest of the time presented DJs, open-mic sessions and parties, as did Naherholung Sternchen, which described itself as "a special place for inspiration, relaxation and collective pleasure" (Naherholung Sternchen).

Naherholung was representative of the several of the musical and social networks into which Improvised Music fitted and that, I would argue, defined its boundaries, ${ }^{32}$ hosting festivals including Jazzkollektiv Berlin's "Kollektiv 
Nights" and the Emitter Microfestival (both 3-4 nights long). Whilst the background and focus of each of these festivals was quite different (Jazzkollektiv concerned with approaches from jazz, and Emitter with sound art), both contained examples of Improvised Music alongside other bands and composed works. ${ }^{33}$

Similarly, Ausland, which in January 2013 promoted Improvised Music events alongside "Paris/Berlin: 20 Years of Underground Techno" (film screening plus turntable performance), "Lyric in Ausland" (an evening of readings), a night of electroacoustic music presented by the electronic studios of the TU, ${ }^{34}$ as well as "Don't give up-you can dance!" ("A new series of dancemusic beyond style at Ausland hosted by the vulva string quartett a.k.a. hanno leichtmann [sic]"), described itself as:

A non-commercially run venue in Berlin for music and performance and related public and nonpublic events ... the focus clearly is on experimental, non-mainstream, demanding, kind of weird stuff which either makes you comfortable or makes you leave the place before you've even finished your first (cheap) drink. (Ausland)

And many venues defined themselves by a similar emphasis on the alternative, the experimental, the strange, the underground and the subversive. NK described itself as:

An artist run independent non-profit organization [sic] that is dedicated to Sound Arts . . . taking part in the creation and support of a culture, with a focus on experimental music, which could be defined as unusual, strange, extreme and unique music that pushes against the boundaries or definitions of what is considered musical. (NK "About Us")

The Sucked Orange Gallery's website described how:

Inspired by the concept of hell by Refus Global de Borduas, the galerie [sic] was a concrete manifestation of total acceptance. In the beginning we created a parallel world with a commercial culture, an aesthetic approach diving in all kinds of forms of expression, in a revitalizing [sic] happening mad creation. All lucid dreamers, spectacle with paintings, sculptures, theatre, cinema, concerts, poetry, and music (popular, Concrete, Electronic, Contemporary, Avant garde, Folk, Experimental, Noise, krautrock and Free jazz). [sic] (suckedorangegalerie "About")

And, as well as hosting concerts, Quiet Cue held installations in its front room (formerly home to the experimental record store Staalplaat), and many musicians made use of Ausland, Boerne45, and the Exploratorium to make recordings, practice, and rehearse during the day time.

\section{Audiences}

Across this network of ad-hoc bars and performance spaces audiences typically numbered between 25 to 60 people and, as most venues were relatively small, many were full with 55-60 and comfortably busy with 25-30.

Festivals such as Kollektiv Nights and the Emitter Microfestival, as well as Splitter Orchestra performances, ${ }^{35}$ typically had audiences of up to 100, and, according to one of the organizers, the A L'Arme festival at Radialsystem $\vee$ (once a year, and with a line-up of international 'stars' of free jazz and Improvised Music, as well as more well-known Berlin musicians) attracted crowds of around 350. From time to time there were audiences of less than 10 people, but these occurrences were relatively seldom.

Audiences were mainly comprised of one third musicians from the scene (of all ages); one third friends and family of the performers (and friends they had brought with them, usually similar in age to the performers); and one third either locals, 'regulars' or other venue-specific audiences.

Particular crowds constituting this last third included students in their mid-20s (Sowieso, The Great Heisenberg), ${ }^{36}$ a particular type of mid-40s intellectual/artistic Prenzlauer Berg resident (at Ausland), and the Ausland staff and other musicians from the Echtzeitmusik-community were all often to be seen at Labor Sonor nights (in KuLe). ${ }^{37}$

Jazzkeller69 attracted an older audience connected with the former-East German jazz scene ${ }^{38}$ the Exploratorium's audience was often comprised of more bourgeois-looking art-and music-lovers in their 50s and above, ${ }^{39}$ and the B Flat usually incorporated a handful of tourists-many of whom appeared to have found the club thanks to a recommendation in a popular Berlin tourist guide. ${ }^{40}$

At some venues, notably the salon and Labor Sonor, the audience's musician-quotient could be even higher, and this was sometimes perceived as somewhat exclusive to the "regular" public. Following a concert, one friend (not at all a member of the scene) commented to me that: 
I would say that $90 \%$ of them were in the Improvised Music scene themselves, and just one or two people were friends-of-friends, and then there was me!

And another listener added that, at the salon:

I took sometimes some friends who were not really into Improvised Music, and for them it was too private.

The audience was generally two-thirds male and one-third female and often highly international-again, varying in relation to who was playing and reflecting the ethnic diversity of the performers. ${ }^{41}$ Announcements (where given at all) were just as often in English as they were in German, and in some venues the first language appeared to be Spanish, French or Portuguese.

Three different circuits existed, in the sense that I would see the same people at Quiet Cue, Ausland, Labor Sonor and Burkhard Beins' nights at $\mathrm{NK}^{42}$ (Echtzeitmusik-scene concerts); Sowieso, The Great Heisenberg and the salon (jazz/Free Jazz/European Improvised Music-related concerts); and Loophole, Madame Claude and NK (noise/drone/industrial/electronic concerts). ${ }^{43}$ Few listeners crossed these apparent boundaries of taste-David Diaz, a 44-year old Spanish postdoctoral student of $19^{\text {th }}$ century German art theory, being one of very few.

Of the handful of other "expert" listeners I met several times during fieldwork, and who themselves were out several nights of the week listening to Improvised Music, were retired architectural historian and bassist Klaus Kürvers (when he wasn't playing himself), his partner Viola (who often took photos), a woman in her early 40s who worked in the film school in Babelsberg (promoting student films), and a software engineer.

And of friends, family and other visitors, and again emphasising the predominantly middle-class/professional nature of the scene, many were from the arts (visual artists, "classical" composers, actors, theatre directors and dancers). I also met a maker of electronic instruments, officials from Berlin's Institut Français, other Improvised Music PhD researchers, translators, a furniture maker, graphic designers, a doctor, a speech therapist, a professor of sociology, a man who described his profession as "harmonizing rooms," a computer programmer, a theoretical physicist, and an Italian farmer (who was taking a year away from his crops, while the land refreshed itself).

While most were there because of friends playing, regular fans and newcomers could discover upcoming events through the echtzeitmusik.de website, a monthly email-shot sent out by Klaus Kürvers, and various posters and flyers (distributed from venue-to-venue). Individual websites of musicians and venues provided further information, and, at the end of 2013, the website echtzeitmusik.de was receiving around 400 visits every day, from approximately 1200 unique users each month (Webalizer). ${ }^{44}$

\section{Economies and Ways of Life}

Performers at most of Berlin's Improvised Music concerts were paid either through a door-money system ${ }^{45}$ or by $^{4}$ Spende (literally 'donation'). At some venues there was no specified minimum donation (Wendel, the salon), whereas at others, prices were fixed anywhere between $€ 5$ and $€ 8$ (Labor Sonor, Quiet Cue, Ausland). As an alternative model, Sowieso, Ackerstadt Palast and Galerie Zeitzone all asked audience members to decide the level of their own entrance fee (between $€ 5-10)$, as did Madame Claude and NK (€1-6 and €6-10 respectively).

As 63-year-old American cellist Tristan Honsinger put it, playing at Sowieso "with more than 30 people a night we almost make 50 a man" and while some concert series, such as Labor Sonor, Biegungen (in Ausland) and Jazzkeller69 were able to offer fixed fees (usually between $€ 75-100$ ), the only fixed-money gigs in Berlin were occasional small festivals such as Kollektiv Nights ( $€ 100$ when they didn't have funding, and $€ 200$ when they $\mathrm{did}^{46}$ and exceptional cases such as the Exploratorium (which offered a fee of $€ 300$ per musician to those performing in the Improvisation International concert series). Another considerable exception was the A L'Arme festival (which reputedly offered up to $€ 1000$ to each performer) ${ }^{47}$ and, in these cases, entrance prices were usually somewhat higher and fixed- $€ 10$ (€8 concessions) at the Exploratorium, and $€ 16$ ( $€ 12$ concessions) for each night of A L'Arme.

Accordingly, only a living on the lowest financial level was possible from Berlin's Improvised Music scene alone. To achieve even this, musicians had to be playing several nights a week in the small venues, with occasional festivals, to make ends meet. While this was how many musicians did choose to live (often hoping that this shortterm sacrifice would pay off in the future), for many others this was a hard choice to make, and such musicians balanced their Improvised Music income with that from other musics or with other jobs entirely.

While many musicians also performed in styles outside of Improvised Music (a subject too extensive to discuss in this brief article), however, the remainder of this section looks at life as a "professional" full-time improviser, as well as the other strategies and life choices made by improvising musicians in Berlin. 
Looking, firstly, to those who sought to make their living exclusively from Improvised Music, and whilst it was possible to survive for some time on income just from Berlin, the aspiration and, for most, the only way to make a living from Improvised Music was to be active on the international circuit-touring clubs and playing in festivals. ${ }^{48}$

International festival fees were usually between $€ 400-600$ (plus flights and accommodation), but occasionally were as high as $€ 1000$ or $€ 1200$ (although such highly paid concerts happened only once or twice a year for even the most "successful" musicians). ${ }^{49}$ Touring was less lucrative-one saxophonist in his mid-30s, relatively well-known in the international improvised noise scene, told me that he'd promised himself, "no more squat tours of 20 gigs in 22 days, coming home with 100 Euros," and relating more to the jazz and Free Jazz scene, 44-yearold bassist Jan Roder added that:

In Germany, the clubs, if you have someone famous with you, like Alex [von Schlippenbach] ... you get $€ 1000$ for a band . . . €1200 maybe. [. . . Sometimes the travelling is already in there, and the hotels they pay-[but] most of the time it's something like 600 for the entire band and you have to pay the travel on top of it . . . it works if you have enough gigs and the travel paid. ${ }^{50}$

Income from recording was also negligible (or even ran at a loss), and many older and more experienced musicians chose to boycott door-money or donation concerts entirely (claiming that as well as being financially inefficient, this system devalued the scene as a whole). ${ }^{51}$

It was widely accepted that, even at the highest level, it was close to impossible to make more than $€ 10-12,000$ per year from Improvised Music alone, ${ }^{52}$ and from this perspective, Berlin was the ideal place to be-old rental agreements signed before gentrification ${ }^{53}$ making it possible to stay living on a low financial level and still devote a substantial amount of time to artistic study and development. ${ }^{54}$

For this reason, it was common for many (especially younger) musicians to live on around $€ 1000$ each month (one musician with a young family told me he needed to bring home between $€ 1500$ and $€ 1700$ ), and many lived in small, shared or unrenovated flats (often still with coal ovens). ${ }^{55}$ Even on this level, however, one highly successful musician, in his late 40s, described his financial situation as "precarious," and one young musician (and one of the most internationally recognised of his generation) told me that:

I still can't really live from it. It's really difficult. My parents never give me money- $€ 50$ each year or something [and] I earn $€ 10,000$ a year on average. That's incredible! [sarcastic, in disbelief]. Or 11. A little more, when you include the schwarzgeld. ${ }^{56}$ So then, what I have in the end, it's not so much-really on the edge of poverty.

And now it's on a really high level, the people I play with, and the circles I move in, but ... it's nuts. [. . . I I don't know if it can get much better-I hope it exists, that it can get better. [ . .] I always have to live from concerts [and] when it doesn't go well for me financially, it doesn't go well. It's really hard. It's a real pressure.

Not all were so discontented however, and for many, the chance to have the time to practice, perform and hone their art was a fair enough exchange for living on a low income, 33-year-old saxophonist Anna Kaluza telling me that:

I don't need much money anyway-it doesn't really interest me to buy something except for food-I mean really I don't need things so much. [. . .] Luckily I have this affordable rent, Berlin is still cheap food-wise ... [and] you can do many [cultural] things for free. Sometimes you can have a very cozy life just playing small gigs and drinking free beer, and go home with your saxophone on your back. [. . .] I mean, I don't say I will be happy with this for all my life . . . but at the moment it's really nice.

And for 46-year-old clarinetist and bass-clarinetist Rudi Mahall, who lived with his partner in the countryside near Berlin (growing his own produce and earning his living purely as a performer of Improvised Music and jazz):

We need nothing, and things go so well for us! I'm always happy about that, and mostly I'm in a good mood because I think I'm really in the right place at the right time. There's no war, I don't have to work, I can just indulge myself in my extremely egoistical vocation, and also just feel great! [laughs] It's amazing!

For many, though, the prospect of such a precarious financial existence was simply too difficult, and many musicians supplemented (or had previously supplemented) their Improvised Music incomes with jobs including copywriting, babysitting, translating Windows software, mastering and mixing recordings, taxi driving, assisting a well-known visual artist, and working in record stores, bookshops, cafes and street markets. The most common non-performing profession was music teaching (generally part-time) and, although this was rarely teaching 
Improvised Music, such work was considered the most efficient way to earn enough so that, as one young cellist told me, she was "free" just to play the music she wanted to play. ${ }^{57}$

Others, however, chose to earn their living entirely independently of their Improvised Music-making. One trumpeter, for example, wrote music for one of Berlin's most famous theatre companies (although, with a young family to support, he commented that he would give this up immediately, if it were possible to earn enough through Improvised Music and his other musical passions). Guitarist, Labor Sonor-promoter, and echtzeitmusik.de website-maintainer, Arthur Rother, ran an IT solutions company and performed just 5-6 concerts each year. ${ }^{58}$ Exceptionally, some musicians were in the position to have had apartments bought outright by their parents, and were able to live comfortably whilst earning relatively little. ${ }^{59}$

The division between musicians that might be termed 'professional'/full-time improvisers and those who engaged in the scene on a more part-time basis was not one that emerged in choices of group constellation (musicians with all levels of engagement played with one another and this distinction did not reflect any differences in levels of proficiency). However, this did have important implications for those pursuing a better situation for Berlin's improvisers, with a clear distinction emerging between musicians aiming to make their income (or a significant part of their income) from Improvised Music-making, and those for whom the financial reward was not so important.

While the first group (which crossed all stylistic and aesthetic boundaries) were concerned with attracting increased funding, and forming associations and professional organizations (IG Jazz, Initiative Neue Musik, Dach/Musik and the Koalition der Freien Szene), ${ }^{60}$ members of the second group were not concerned with such lobbying or political activity, and were either content with the situation as it stood, or pessimistic that it could change for the better.

\section{Conclusion}

Berlin's Improvised Music scene of 2012-13 was an essential meeting point for musicians from all over the world, and one of many local scenes (or group of local expressions) within the context of an international 'translocal' Improvised Music community (Bennett and Peterson 6-8). ${ }^{61}$ This social group belongs to the wider historical context of American and European Improvised Music, and also references (musically) and intersects (socially) with several of the disciplines that have inspired it (jazz, Neue Musik, Electronic Music, noise music, avant-pop, etc).

The scene encompassed those of all ages, however, whilst professing to welcome those from all backgrounds and despite a perceived increase in diversity in recent times, Berlin's Improvised Music community was predominantly white, middle-/professional-class and male (also in terms of audience).

Migration, gentrification and the fall of the Berlin Wall in 1989 have all contributed to Berlin's ongoing position as one of the world's most important cities for Improvised Music, and it is clear that the city's unique past and current economic climate are essential to the kinds of constantly changing "ad-hoc" venues, idiosyncratic musicians and risk-taking artistic endeavours that have been taking place in the city for the last 20-25 years.

Whilst remaining almost entirely hidden from view in mainstream music industry terms, a network of intimate venues and dedicated musicians continue to produce a highly developed and unique music, and even though the financial rewards of such a life may not have been so high in conventional terms, performers found a variety of means to dedicate as much time and energy as possible to their artistic output (living on a low financial level, teaching, working part-time jobs).

Although this is not detailed in this paper, such time was necessary for the practice, preparation and rehearsal necessary for the development of a strong individual voice and the flexibility and awareness to interact meaningfully in a group context (as well as for booking concerts and organizing recordings), and for many musicians, the representation of their political convictions through their art was significantly important to merit the acceptance of such a precarious financial situation.

This was often a conscious choice and a question of identity-living outside of the conventional structures and expectations of mainstream society, whereas for others it continued to be a source of frustration and a situation in need of improvement, change, increased recognition, and funding.

In 2015, the scene continues to grow, and more and more musicians arrive here every day-Berlin remains a hotbed of musical experimentation. In my opinion, and in the opinion of many of those I interviewed, Improvised Music is still something to be experienced (primarily) in its live form, and it is my hope that this brief paper will provide a tempting first glance into Berlin's improvising community, as well as its constitution, its ideologies and its practicalities. 


\section{Notes}

1 For the purposes of this article, the term "Improvised Music" refers to the tradition that emerged from 1960s American jazz and free jazz, continued in Europe with the considerable influence of "contemporary" classical music, and that remains, arguably, one of today's most misunderstood and under-represented musical genres.

2 These distinctions are elaborated further in my thesis.

3 The musician-run website http://www.echtzeitmusik.de contains concert listings and information relating to the scene, and is generally held to be a reliable source of information for current events in Berlin.

4 This meant an average of 2-3 concerts each day, although sometimes there were up to 9 or 10.

5 From two evenings at Ausland called KlangKüche (lit. "SoundKitchen”), where chef II Marchese Gaetano Ciurcina cooked Neumanndorle e menta con crostino di caponata e Fettunta (for inside-pianist Andrea Neumann) and Biscotto al carrubo Voutchkova (for violinist Biliana Voutchkova), among other musician-themed dishes.

$6 \quad$ Many played two or more instruments.

$7 \quad$ This club was based around musicians with interests in jazz-related musical genres.

8 One interviewee admitted that, despite this policy, they still sometimes found it difficult to find enough female performers.

9 Pianist Irene Schweizer and vocalist Maggie Nichols are perhaps the most notable exceptions. See (Oliveros 50-70) for more on international contemporary women improvisers.

10 Andrea Neumann recalled being on tour in America, where a local sound engineer attempted to "help" her to remove noises from her mixing desk which were actually part of the music, something she suspected would not have happened had she been a man. Vibraphone player Els Vandeweyer also spoke of the difficulty of starting a group with three male first generation improvisers, who were initially skeptical at playing with a young female performer.

11 Over the course of the year it was possible to see most of the "big" international names of Improvised Music, such as Peter Brötzmann and Paul Lovens, Americans Peter Evans, Ken Vandermark and Anthony Braxton, the English saxophonist Evan Parker, and Dutch drummer Han Bennink. Many visiting musicians would use the opportunity of a well-paid concert (in a festival or at the Exploratorium) to stay in Berlin for a number of days, and perform door-money gigs at smaller venues with new acquaintances, younger musicians, and old friends alike.

12 This change was inspired largely by the fall of the Berlin Wall in 1989, and, as Klopotek puts it: "At this point in time the relocation of the government to the new capital was a done deed [and] word got around that there was-especially in the central east part of the city, taken by surprise at its own reunification-low cost living space en masse, [and] that a lot of urban spaces and structures were not demarcated, thus offering space for artistic proliferation." (Klopotek 65).

13 Just as with gender, this was remarked on as strange in a scene supposedly open to all, however this was also a reflection of contemporary Berlin (and Germany as a whole), which, having only limited colonial history, has nothing like the cultural diversity of London or Paris. At the end of 2013, of Berlin's 3.52 million official residents, $85 \%$ were ethnic German, $6 \%$ were from the European Union, and 5\% originated in the rest of Europe, with the remaining $4 \%$ accounting for all other nations (14\% of these were North American) ("Statistischer Bericht").

14 Networks were created using the 5, 10, 20 (and so on) participants with the highest degree centrality measures. Network density was then calculated for each of these. This showed that despite an overall network density of 0.004 (only $0.4 \%$ of all possible connections had been made by performing together), with the 175 most central participants selected this rose to $7.5 \%$, with 67 participants to $20 \%$, with 21 to $40 \%$, and between the top ten participants, $70 \%$ of all possible connections had been made. As Crossley points out, there are no absolute or objective criteria for what constitutes a high-density network [Crossley, 2008], however, seeing as he considers $25 \%$ for a network of 40 people (in the case of 1970 s UK punk) to be high-density, in the case of Berlin's core Improvised Music community, this figure was already somewhat higher. 
15 My research also suggests a range of differing-yet-interconnected aesthetic distinctions used by musicians and listeners to distinguish between Improvised Music practices, and this subject, as well as how performers created their own musical lives in these terms, is explored in greater depth in my thesis.

16 I use the term Neue Musik to define what otherwise might be called contemporary (composed) classical music or New Music. This was the term that most participants used to refer to this area, even when speaking English or when German was not the first language.

17 As well as the use of UCINET's Ego Network function.

18 Such as Radialsystem V (most famously home to choreographer Sasha Waltz).

19 The district of Kreuzberg is divided into two areas-postcode 10999, around Kotbusser Tor (with a large Turkish population), and the more-expensive and more-gentrified Bergmannkiez, postcode 10961. During my fieldwork, Neukölln was in a constant state of flux, with cafes, bars and warehouses slowly replacing corner darts bars such as Aller-Eck (on the corner of Aller Strasse), Alptraum 3 ('Nightmare 2') and Bierbaum 3 ('Beer Tree 3'). Boddinstrasse and Leinestrasse U-Bahn stations (home to Sowieso, The Great Heisenberg and Quiet Cue) were being entirely renovated over those months, and I often saw notices in ground floor residential windows urging incoming tenants not to pay more than a certain level of rent, so as not to inflate the prices for local people (nk44).

20 Closed for the period in between, the salon were asked to leave their previous location for undisclosed reasons, the landlord apparently not even open to discussion. Those running the salon asked that the place remained anonymous: "[Our] policy has always been "we don't exist", it's better that was I think... if people read it that know [us] then they will know, and if people don't know, they don't know. And if they're curious they will find it."

21 Sowieso means "anyway" or "anyhow", Ausland "foreign country" (but with the political implication of being an exception not belonging to Berlin, Germany, or perhaps anywhere), Naherholung Sternchen "starlet local recreation spot," Jazzkeller "jazz cellar", and Lichtblick Kino either "ray of hope cinema" or "bright spot cinema" (also in the sense of being something of an exception in the surrounding greyness). The Great Heisenberg was, presumably, named after the protagonist of the TV series Breaking Bad.

22 In terms of alcohol licensing and paying the GEMA (GEMA, concerned with collecting royalties, is the equivalent of PRS/MCPS in the UK, Sacem in France, or ASCAP/BMI in the USA). Typical of the attitude of many, one promoter told me that "It would actually be quite impossible for the GEMA to interfere with [our] business, because [our venue] is private. And in privacy you can do whatever you want to. And [we] will stay private, and will always be private. [. . .] When people say it's an illegal bar, I say 'Call it that way if you want to, no problem for me', but no, it's not. It's totally legal. I'm not allowed actually to sell drinks. But officially I don't sell-it's a present, and I receive a present. It's only [that] I say how the present goes! [laughs]. So I don't think that's ever going to be a problem."

23 The offices where those of the BVG (Berlin's public transport agency), and the entrance to Marie Antoinette was opposite where fines were paid if caught without a valid ticket on the S- or U-Bahn.

24 This stairway was already painted over during renovation in around 2011, a sign of gentrification to come.

25 "Work makes you free. Not working makes you freer," a play on the phrase used by the Nazis and often erected over the entrance to WWII Concentration camps.

26 The term Echtzeitmusik (literally "Real-time music") originated in mid-1990s Berlin, primarily as a means of distancing a younger generation from the older Free Jazz-related scene. The distinctions between Echtzeitmusik as a music and a social milieu are heavily contested (Beins et al.), however, in this case, I use the term to describe the network of musicians and venues that evolved during this period, and which encompassed Improvised Music, electronic music, noise, avant-pop/rock, Neue Musik and performance art.

27 The first concentrated period of Improvised Music in Neukölln began around this time.

28 Blazanovic 33-53

29 Cf. suckedorangegalerie "Why don't you call the police". To protect itself, there was not even a sign outside, no lights, and no sign from street-level that anything was going on within. 
30 The other clubs were the legendary Schokoladen rock club and the Club der Polnischen Versagers (literally "Club of the Polish Losers"). This former squat, in now-gentrified Mitte, was threatened with extinction from 2011 onwards, but was able to continue thanks to the philanthropy of a Swiss foundation (Stiftung Edith Maryon), who, reportedly, had bought the whole building and offered the venues an ongoing lease at prices far below the market rate, on the condition that they continued promoting non-commercial "free" culture (Stiftung Edith Maryon).

31 See the next section of this article.

32 Background music, played before and after performances, also offered some clues to this contextSowieso's Marc van der Kemp often spinning classic 1950s jazz records, the Ausland team sometimes playing recordings of Alvin Lucier pieces, and Madame Claude's DJs playing a wide range of experimental electronic music.

33 Pianist Marc Schmolling, one of the founder members of Jazzkollektiv Berlin, described that, "Each of us has got a different style and taste, some of us really write more than they improvise and vice versa. But definitely, improvisers and improvisation are part of 'our world,' and we also have often guests that can be related more to the 'Echtzeitmusik-scene' rather than the jazz-scene . . . I think we don't care which format, improvised or written, an artist uses to create and perform music." On the other hand, Emitter Micro festival's programme and advertising stated that, "Emitter Micro is a 3-day festival of sound art in Berlin [. . .] [proposing] a selection of international and Berlin-based artists from multiple contemporary sound practices and genres; be it electronic or acoustic, digital or analog, installed or performed, improvised or composed."

34 Technische Universität Berlin, Berlin's technical university.

35 Splitter Orchester was a highly respected Post-Reductionist orchestra of 24 musicians from the Echtzeitmusik scene, who performed improvisations, conceptual works and occasional Neue Musik works (for example, the collaboration with composer Mathias Spahlinger at the 46. Internationale Ferienkurs für Neue Musik Darmstadt 2012, one of Germany's most important Neue Musik festivals) (Splitter Orchester "About"). Splitter Orchestra performances were something of a rarity, occurring only once or twice a year in Berlin itself.

36 This part of Neukölln was a popular student area, owing to low rents.

37 Ausland was run by a small team of volunteers.

38 Promoter Assi Glöde had previously been responsible for the Parkhaus Treptow, arguably East Berlin's most important venue for Free Jazz.

39 The likes of whom probably would not be seen in more underground venues, such as Sowieso or Loophole.

40 As with the students in Sowieso, often these visitors were no longer to be seen by the second set of a more adventurous Improvised Music concert.

41 See Table 2.

42 A short concert series under the name Perceptive Turns.

43 Again, these aesthetic distinctions are made more clearly in my thesis. These circuits could also be identified by the distribution of leaflets, posters and flyers through these networks (the B Flat's advertising, for example, never appeared in Loophole or in Ausland).

44 Thanks is due to Arthur Rother for access to the echtzeitmusik.de web analytics archive.

45 Performers are paid directly in relation to the income from tickets or the entrance price, and their income is dependent on that price, and the size of the audience (as opposed to receiving a fixed fee).

46 Such funding, for small or mid-level venues hosting festivals or concert series, typically came from the Berliner Senatskanzlei für Kulturelle Angelegenheiten (Berlin's state regional office for cultural affairs), as well as local administrations such as the Bezirksamt (local town hall) of Pankow and Neukölln, and the Deutsche Musikrat and Impuls Neue Musik (all of which regularly awarded funding of $€ 500$ to $€ 3000$ or $€ 4000$ ).

47 Such larger-scale events were generally supported by awards from funding bodies such as Hauptstadtkulturfonds (whose applications began at $€ 50,000$ ), and these applications were often mediated 
through a small number of arts professionals with interests in Improvised Music, such as Splitter Orchestramanager and Ausland-founder Gregor Hotz, or Melanie Rossmann of the agency Aufklang (who was also instrumental in writing smaller individual applications to the Senat).

48 Konfrontationen (Nickelsdorff, Austria), Festival Densités (Fresnes-en-Woevre, France) and Music Unlimited (Wels, Austria) were all popular festivals among musicians. Touring was pan-European, but there was also a considerable demand for Improvised Music in Japan and in North America (exchanges with the Chicago scene not being uncommon). It was also common for musicians moving to Berlin to arrive with enough savings for 1 or 2 years - using this time to investigate the local scene before a harder reality sometimes set in.

49 Many musicians noted that sometimes there were years with none of these concerts at all, and one, in his mid-30s, alleged that, "it's super hard to get these gigs on the festivals, and also in this Improvised Music world there's a mafia of people who play everywhere all the time. It's hard for the younger generation."

50 Touring groups were mainly trios or quartets. Usually tours consisted of a combination of club and festival dates and, as bassist Clayton Thomas explained, a certain flexibility was necessary for making things work. For Thomas, "A good gig ... is 400 [Euros] minimum [. . .] and travel and a hotel, that's my criteria, I'm happy to go and do that. [. . .] 300? If there's three in a row, fucking awesome, no question [. . .] if there's three [at] even 200, I don't care [. . .] if we're playing, and were doing like a week, and there's some gigs that pay 100, and there's a gig that pays 200 , and there's one gig that pays 800 or 600 or whatever, it's fine, great."

51 Many were concerned that this system implied to a wider public that Improvised Music was something "for free" and therefore worth nothing (compared to other artforms). Others, however, saw local/door-money concerts as opportunities to test out new groups in front of an audience before taking them to festivals, as "paid practice" and as a space to take risks, as well as to grow their own social network (for this reason these concerts were particularly important to newcomers). For many, their willingness to play in such venues also depended on the place itself, the generosity of the hosts (receiving respect, free food and/or drinks), as well as the importance of the chance to perform an intimate concert to a quiet and discerning audience.

52 By means of comparison, in 2011, the average annual income in Berlin was $€ 30,144$ for women, and $€ 38,856$ for men (Statistik Berlin-Brandenburg "Gender Datenreport").

53 Rent increases in Berlin are heavily capped, and it was common for new tenants to take over an apartment directly from the previous tenant and not via an estate agent, firstly, so that the owner couldn't raise the price, but secondly, to avoid paying estate agents' commissions (which could be equivalent to 2 months rent, or more).

54 As I show elsewhere in my thesis, there were also non-musical political/ideological reasons for these choices, as well as the fear of being perceived as "selling out" by diluting their musical output.

55 Up until the 1990s it was common for many buildings to be heated with individual coal ovens, before they were saniert (renovated) and central gas heating for the whole building was installed, often leading to substantial rent increases. Many had monthly rents of $€ 250-300$ and one couple in Neukölln paid as little as $€ 130$ each (all prices here are "warm" - including water and heating).

56 Cash-in-hand that's not officially declared.

57 Only the most internationally renowned musicians gave occasional workshops and private lessons in Improvised Music practice, and younger musicians pointed out several times that their older mentors often refused to 'teach' formally — choosing not to accept money, but to have a "jam" session or play a low-profile concert so that younger musicians could learn by "doing".

58 These concerts were mostly with the group "SINK".

59 Some such musicians were met with considerable hostility from others, one musician commenting, of another, that, "[You] own your apartment because your parents gave it to you [. . .] [and] you don't have to make any money, so you can [. . . ] fucking judge everyone, and make a sine wave for an hour and call it art".

60 A subject too vast for this article, these matters are explored in more depth in my thesis.

61 Bennett and Peterson describe how the term 'translocal scene' "refers to widely scattered local scenes drawn into regular communication around a distinctive form of music and lifestyle", whereas a 'local scene' "corresponds most closely with the original notion of a scene as clustered around a specific geographic focus . . . an equation 
of 'scene' with 'community', [and with] locally situated pockets of grassroots musical creativity distinct from global mainstream music styles" (Bennett and Peterson 6-8).

\section{Works Cited}

"About Ausland." Ausland. 2013. Web. 19 Jan. 2013.

"About: Naherholung Sternchen." Naherholung Sternchen. Web. 14 Jan. 2014. http://www.naherholungsternchen.de/about/

"About" Sucked Orange Galerie. Web. 26 Feb. 2013. http://suckedorangegallery.wordpress.com/about

"About Us": N.K. (2013). Web. 14 Jan. 2014. http://www.nkprojekt.de/about/

Beins, B., Kesten, C., Nauck, G., and Neumann, A. Echtzeitmusik Berlin: Selbstbestimmung Einer Szene/SelfDefining a Scene. Hofheim : Wolke Verlag, 2011. Print.

Bennett, A. and Peterson, R. A., eds. Music Scenes: Local, Translocal, and Virtual. Nashville: Vanderbilt U P, 2004. Print.

"Berlinsplitter: About the Artists." Splitter Orchester. Web. 2 Feb. 2015.

http://www.berlinsplitter.org/index.php?article_id=1

Blazanovic, Marta. "Venues." Echtzeitmusik Berlin: Selbstbestimmung einer Szene/Self-defining a Scene. Eds. Beins, B., Kesten, C., Nauck, G., and Neumann, A. Hofheim: Wolke Verlag, 2011. Print. 33-53.

Borgatti, S., Everett, M., and Freeman, L. "UCINET 6 For Windows: Software for Social Network Analysis." Analytictech.com. 2002. Web. 1 Oct. 2012.

Crossley, N. "Pretty Connected: The Social Network of the Early UK Punk Movement." Theory, Culture \& Society, 2008, 25:6. 89-116. Print.

"Gender Datenreport: Berlin 2012." Statistik Berlin-Brandenburg. Berlin, Brandenburg: Amt für Statistik BerlinBrandenburg / Senatsverwaltung für Arbeit, Integration und Frauen, 2012. Web. 25 Nov. 2014. https://www.statistik-berlin-brandenburg.de/gender/kapitel2012/einkom_1.htm

Klopotek, F. "Bye! Forty Years of FMP." FMP: Im Rückblick - In Retrospect. Berlin: FMP, 2010. 54-68. Print.

"Nachrichten aus Nord-Neukölln." N.K. Web. 14 Jan. 2014.

Oliveros, P. "Harmonic Anatomy: Women in Improvisation." The Other Side of Nowhere: Jazz, Improvisation, and Communities in Dialogue. Eds. Daniel Fischlin and Ajay Heble. Middletown: Wesleyan U P, 2004. 5070.

"Schokoladen." Stiftung Edith Maryon. Web. 5 Dec. 2014.

"Statistischer Bericht: Einwohnerinnen und Einwohner im Land Berlin am 31." Statistik Berlin-Brandenburg Berlin: Brandenburg: Amt für Statistik Berlin-Brandenburg, 2013. Web. 25 Nov. 2014. https://www.statistikberlin-brandenburg.de/Publikationen/Stat_Berichte/2014/SB_A01-05-00_2013h02_BE.pdf

Webalizer (2014). Webalizer: Usage Statistics for Echtzeitmusik.de. Web. 14 Jan. 2014.

“Why don't you call the police?" Sucked Orange Galarie. Web. 12 Mar. 2013. 